\title{
ASSESSMENT ON THE EFFECTIVENESS OF BPR IMPLEMENTATION IN COMMERCIAL BANK OF ETHIOPIA, THE CASE OF SELECTED BRANCHES IN MEKELLE CITY - CUSTOMERS PERSPECTIVE
}

\author{
Mohammed Mohammednur \\ St. Mary's University \\ School of Graduate Studies \\ Department of Business Administration \\ Addis Ababa, Ethiopia
}

\begin{abstract}
The increasing competition in the service sectors particularly in the banking industry raises the need for transformation of the way banks serve their clients. Among the modern management tools used by many local and international businesses to transform their organization is Business Process Reengineering (BPR) which seeks to radically transform the business process. The intention of this study was to analyze the effectiveness of BPR implementation considering Commercial bank of Ethiopia (CBE). Its effectiveness is measured from the customer's perspective to see the improvements made on the customer service delivery. The dimensions used to measure the changes are the speed of the service delivery, the customer handling, the flexibility of the procedures and the customer satisfaction. These issues are measured using a descriptive research by comparing before and after implementation of BPR. The data were gathered from customers of the bank through self-distributed questionnaires. To analyze the data a simple descriptive statistical tools are used. The result shows that the bank has radically improved its service delivery speed and significantly reduced the customers queuing time. However, the changes made on such factors as customer treating, understanding customers' needs, flexibility of the procedures, are relative changes as per what BPR should come up with. It can be generalized that the bank's BPR implementation particularly service delivery is not as effective as it was intended. The researcher, therefore, likes to suggest that still the bank is required work more with the changes focusing on the service delivery and customer satisfaction as per BPR recommendations to make them significant changes.
\end{abstract}

Key words: BPR, effectiveness, customer handling, queuing time, procedure flexibility

\section{INTRODUCTION}

\subsection{Background of the Study}

Business process reengineering is known in short as BRP and is considered a main way in which organizations become more modern and efficient. Business process reengineering (BPR) is the analysis and redesign of workflow within and between enterprises. It is a management approach aimed at making improvements to your business through elevating the efficiency and effectiveness of the processes that exist within and across organizations. (Hammer M. 1990) the emergence of globalization and growing competitiveness of world markets have made organizations throughout the world to continually look into different management philosophies and techniques purposely to make their business operations competitive. The management discipline is facing massive challenges. Entirely new business models are enabled while many traditional business models become obsolete. A wide range of systems and approaches such as Management by objective (MBO), outcome-based evaluation (particularly to non-profit organizations), benchmarking, TQM (total quality management), Business Process Re-engineering (BPR) etcetera have been deployed as drivers to improve organizational competitiveness and increase organizational performance (Lee and Oakes, 1996). However, the fact that most of the systems and approaches of increasing performance have done little more than locking in incremental gains, companies have 


\section{International Journal of Engineering Applied Sciences and Technology, 2019 Vol. 4, Issue 6, ISSN No. 2455-2143, Pages 29-36 \\ Published Online October 2019 in IJEAST (http://www.ijeast.com)}

turned towards a more radical and new approach Business Process Reengineering (BPR) - which they expect to yield breakthrough levels of improvement (Krcmar and Schwarzer, 1998).

As cited by Abdurezak,MacIntosh, 2003 has stated that since the late eighties, BPR has established itself as one of the attractive change management options for coping and adapting to the new competitive market environment. Research studies have shown that BPR is still very much alive and well both in the public and private organizations throughout the world. Crucially, BPR seeks to achieve, by a systematic approach, various organizational objectives, which deliver a real enhancement to the operations of the business (Harrington, 1992), and for this reason, BPR is regarded as a viable change mechanism (Coulson-Thomas, 1996; Nelson and Coxhead, 1997; McAdam, 2000; Collins, 2001), especially in areas such as reduction in operational cost, major improvements in customer and client or staff quality of service and innovation in business (Stoddard and Jarvenpaa, 1995).

\subsection{Statement of the Problem}

In response to competitive pressures, customer demands and ever-changing regulatory conditions, many companies are fundamentally rethinking the way they do business. Service firms are different from manufacturing businesses in the fact that their survival is highly determined by the way they serve their customers, the service blueprint they follow, and the their promptness to any enquiry raised by the clients.

Despite of this, it has long been observed that many customers of Commercial bank of Ethiopia have had complaints on the services being delivered by bank compared to other banks. Among the complaints there is long queue, lack of cooperativeness of workers, lack of service variety in one window, lack of immediate response for customer request, lack of complaint handling procedure and the like. As part of the solution for these problems, the bank has decided to rethink its service delivery process and to introduce a new system that restructures the overall workflow of the bank.

Theoretically, management can follow two types of improvements that is innovation (radical improvement) and continuous improvement. If BPR is considered as a radical improvement, it is expected to come up with radical improvements in the service delivery process of the bank particularly on the problems identified above against which the effectiveness of the system is measured.

From customer service point of view, the new system is expected to solve the above mentioned problems. However, once the system is implemented the bank did not evaluate whether the system is come up with the required level of improvement on the specified areas.

Then this study is intended to evaluate the effectiveness of the implementation of Business Process Reengineering considering Commercial Bank of Ethiopia In some selected branches of Mekelle district.

The effectiveness of the system was evaluated in terms of reducing the time duration service delivery process takes, flexibility of operating procedure, and improvement in customer service in general.

\subsection{Research Objectives Objectives of the Research}

This research is designed to achieve the following objectives:

- To examine the improvements made:

- In quality of service

- Speed of service delivery

- Flexibility of procedure

- Customer handling

- To analyze customers satisfaction after the implementation of BPR

\subsection{Scope of the Study}

By its nature BPR is a wider concern which address various changes made in one organization from the top management to the operational level. As a result, this research has its own coverage both conceptually and geographically. Though the system is implemented through the structure of the bank, the concern of this study was confined to services delivery process from the customers view point. It doesn't cover the internal office works. Geographically, the bank has many branches and sub-branches throughout the region. However, due to geographical disparity of the branches and budget contrarian, this study output only represents the selected branches of Mekelle district (Capital city of Tigrai region).

\section{REVIEW OF RELATED LITERATURE}

Business process reengineering (BPR) has been receiving attention from industries as well as the academic community, because it is likely to change management practice and working processes in organizations in the future. However it is commonly agreed that BPR is important but also problematic. In this chapter we explore the definitions used to describe business processes and $\mathrm{BPR}$, the principles and assumptions of BPR.

Competition is dynamically increasing with respect to quality, price, selection, service and promptness of delivery. Removal of barriers, international cooperation, technological innovations cause competition to intensify. 


\section{International Journal of Engineering Applied Sciences and Technology, 2019 Vol. 4, Issue 6, ISSN No. 2455-2143, Pages 29-36 \\ Published Online October 2019 in IJEAST (http://www.ijeast.com)}

All these changes impose the need for organizational transformation, where the entire processes and organization climate and organization structure are changed.

\subsection{What is the Business Process Re-engineering?}

As cited by Yih-Chang Chen (2001), it is argued by some researchers (for example, van Meel et al., 1994; MacIntosh and Francis, 1997; Peltu et al., 1996) that there is no commonly agreed definition of BPR. Peltu et al. consider that this lack of an accepted definition of BPR makes it difficult to assess the overall success or failure of its concept. Thus it is essential to make clear what the definition of BPR is before we propose any framework and techniques for BPR. The book reengineering the Corporation: A Manifesto for Business Revolution by Hammer and Champy (1993) is widely referenced by most BPR researchers and is regarded as one of the starting points of BPR. The following is their definition of BPR: [Reengineering is] the fundamental rethinking and radical redesign of business processes to achieve dramatic improvements in critical, contemporary measures of performance, such as cost, quality, service and speed. (p. 32).As cited by Hezron M. Osano, David M. Okwena, Hammer and Champy in their revised edition (2009), defined BPR as the radical rethinking of existing organizational functions and operational flows with the aim of achieving dramatic improvement.

Another BPR father, Davenport (1993), describes 'business process redesign' as: ... the analysis and design of workflows and processes within and between organizations.

Hammer and Champy provide the following definitions:

Reengineering is the fundamental rethinking and radical redesign of business processes to achieve dramatic improvements in critical contemporary measures of performance such as cost, quality, service and speed.

Process is a structured, measured set of activities designed to produce a specified output for a particular customer or market. It implies a strong emphasis on how work is done within an organization. Thomas $\mathrm{H}$. Davenport, "Need radical innovation and continuous improvement? Integrate process reengineering and TQM." Planning Review 21.3 (1993): 6-12.

Reengineering posits a radical new principle: that the design of work must be based not on hierarchical management and the specialization of labor but on end-to-end processes and the creation of value for the customer. Hammer and Champy (1993)
Reengineering is the fundamental rethinking and radical redesign of business processes to achieve dramatic improvements in critical contemporary measures of performance such as cost, quality, service and speed. (Ibid)

As stated by Yih-Chang Chen (2001), Vidgen et al. (1994) define the central tenets of BPR as:

$$
\begin{aligned}
& \text { radical change and assumption } \\
& \text { challenge; } \\
& \text { process and goal orientation; } \\
& \text { organizational re-structuring; } \\
& \text { the exploitation of enabling } \\
& \text { technologies, particularly information } \\
& \text { technology. }
\end{aligned}
$$

\section{Objectives of BPR in service industries}

Organizations considering BPR should define their objectives. This allows management's vision of the future to be compared to the current state. Once defined, objectives will provide the goals your improved processes will strive to obtain.

\section{Common objectives of BPR in service industries include:}

- Reduced waste and increased efficiency of the service delivery process

- Increased consistency of the service outcome

- Increased customer satisfaction

- Increased throughput; more business processed using the same resources

- Reduced operating costs/higher profitability

Once the objectives are determined, the next step is to meticulously define the current state of your internal processes. Documenting the current state involves gathering and organizing data through a structured approach. Doing this provides a better understanding of the organization, and it may uncover hidden inefficiencies and opportunities for service improvement previously unknown to management.

\section{Business Process Re-engineering in Banking}

Satyanarayana S. V. and Kavitha N. V.(2011) in their study entitled "Impact of Business Process ReEngineering in Commercial Banks on Customers' stated that the objective of BPR initiative is to strengthen Bank's ability to acquire new customers, build lasting relationships with existing customers and increase customer satisfaction through world-class service quality. The BPR project is also to simplify and redesign business processes to fully leverage the Core Banking Solution (CBS) platform. 


\section{International Journal of Engineering Applied Sciences and Technology, 2019 Vol. 4, Issue 6, ISSN No. 2455-2143, Pages 29-36 \\ Published Online October 2019 in IJEAST (http://www.ijeast.com)}

In Nigeria, changes in the financial market, customer demands and increasing competition forced banks to re-engineer their business organizations. Nigerian banks had to come up with innovative ways through $\mathrm{BPR}$ in order to increase and retain their customer base and improve on service delivery.

Sidikat (2008) has conducted a study on impact assessment on reengineering indicating that BPR has become an important tool for any corporate organization that is seeking to achieve cost leadership strategy in its operating industry and environment and intends to improve in their current organizational performance. For organizations striving to operate effectively and efficiently, it is recommended that BPR remains an effective tool.

\section{BPR and Customer Focus}

Customer demands drive most BPR initiatives and more so in the service industry (Hammer \&Champy,2009). The customer focused approach has also been moved further to include the internal customer. There have been attempts by recent approaches to redress the balance and have argued that customer support should be a key ingredient in process redesign ventures as opposed to the current methodologies that maintain focus on workflows and little regard for the customer (Walden, 2009). The importance of innovation is known to most of the more enlightened firms, it is not all about process efficiency but also customer experiences and customer expectations. Starwood Hotels for instance, talks about the need to execute across business silos rather than innovation and efficiency within specific processes. Citibank's CEO (chief executive officer) noted that as improvements increase, expectations also increase and therefore customer perceptions will change subsequently driving you to places you never knew existed (Walden, 2009), this is the more reason to embrace a systematic business process improvement with the customer in focus. The reviews of all these idea give us BPR implementation reorganizes the overall structure of an organization in general and the customer service delivery in particular.

To generalize this section, BPR has its own scientific ground supported by different scholars as it simplify the customer service process and internal operations. Thus, the paper tries to address the extent to which the new system, BPR, implemented in financial institutions is effective in terms of the identified dimensions.

\section{METHEDOLOGY OF THE STUDY}

\subsection{Study Design}

A research design is a plan, structure and strategy of investigation so conceived as to obtain answers to research questions or problems. The plan is the complete scheme or programme of the research. It includes an outline of what the investigator will do from writing the hypotheses and their operational implications to the final analysis of data. (Kerlinger 1986: 279)

The study was aimed at assessing the effectiveness of the new structure implemented in the bank from the customer's point of view. A descriptive research design was followed to know the customers view on the service delivery improvement. According to Kumar, Ranjit, 2005Descriptive research attempts to describe systematically a situation, problem, phenomenon, service or programme, or provides information about, say, living condition of a community, or describes attitudes towards an issue.

\subsection{Methods Data Collection Primary data}

Basically the data source for this study was customers of the bank. These customers consist of account holders, money transfer users, and some borrowers. To obtain the primary data, the researcher has distributed semi- structured questionnaire that consists of closed ended and open ended items.

\section{Secondary data}

On the other hand, to obtain the secondary data some documents related to the title have been searched. These include the organizational reports, previous conducted researches, internet and the like. Since the study is intended to see the customers' attitude, the data were qualitative data that are expressed based of their feelings.

\subsection{Target Population and Sample Determination} The bank has a district office and six branch offices in Mekelle city. These offices were taken as target branches for this study considering their high traffic and number of customers. This made the researcher to get access of data required to answer the basic research questions.

\section{Sample size}

The bank has a diversified group of customers. Some of them are account holders; some of them are also transfer service users; still some of them are debtors. Although obtaining the data about the number of account holders and debtors is possible, it was 


\section{International Journal of Engineering Applied Sciences and Technology, 2019 \\ Vol. 4, Issue 6, ISSN No. 2455-2143, Pages 29-36 \\ Published Online October 2019 in IJEAST (http://www.ijeast.com)}

difficult to determine the number of other service users. As a result of this, it is difficult to get the total population of customers.

Therefore, to determine the sample size a formula for infinite Population given by Godden (Godden, 2004) was followed.

$$
S S=\frac{Z^{2} \times(p) \times(1-p)}{C^{2}}
$$

SS $=$ Sample Size

$\mathrm{Z}=\mathrm{Z}$-value(e.g., 1.96 for a 95 percent confidence level)

$\mathrm{P}=$ Percentage of population picking a choice, expressed as decimal

$\mathrm{C}=$ Confidence interval, expressed as decimal (e.g., $.04=+/$ - 4 percentage points)

Accordingly, considering $90 \%$ of confidence level ZValue is taken 1.645 from $\mathrm{z}$-table, the confidence interval is to be $4 \%$ and $10 \%$ of the population picking a choice, the following sample size was determined.

$$
\mathrm{SS}=\frac{\mathrm{Z}^{2} \times(\mathrm{p}) \times(1-\mathrm{p})}{\mathrm{C}^{2}}=\frac{1.645^{2}(0.1)(0.9)}{0.0016}=\underline{\underline{132}}
$$

Based on the above, 132 customers were considered as sample size for this study. To pick an individual respondent, the researcher has made personal visit of the branches and selected the customers using convenience sampling technique.

\subsection{Method of Data analysis}

Once the data are gathered through the instrument and the entire preliminary scan is conducted, a simple descriptive analysis was conducted using table's frequency and percentage. Finally the analysis was supported by adequate interpretation and inference.

To conclude the research has used an appropriate methods with its adequate and scientific justification.

\section{Data Analyses}

The sample size of this research was 132 respondents and the researcher has distributed 132 to customers of the bank. From these, only 108 questionnaires were collected, which accounts for $82 \%$ of response rate. Out of 108,8 questionnaires were not filled adequately and the analysis was done based on 100 respondent's feedback

This part presents and analyses the data gathered from the target customers.
Table 4.1. Customer's years of contact with CBE

\begin{tabular}{|c|r|l|}
\hline Alternatives & Frequency & Percent \\
\hline 1-3 years & 22 & 22.0 \\
\hline 4-6 years & 18 & 18.0 \\
\hline 7-9 years & 40 & 40.0 \\
\hline >9 years & 20 & 20.0 \\
\hline Total & $\mathbf{1 0 0}$ & $\mathbf{1 0 0 . 0}$ \\
\hline
\end{tabular}

The above table shows the customers' years of contact as a customer of the bank. The length of their contact with the bank determines their understanding on the service delivery system both before and after the new system, BPR, is introduced. As the data shows even though $22 \%$ of the customers are being served for less than 3 years, majority of them are users of the banking service long period. This gives us good indication that the selected customers may have adequate understanding about the changes made through BPR

From this data we can observe that, most of the customers are partner of the bank, and this enables the researcher to get detailed information about the banks' service before and after BPR implementation.

Table 4.2. Customers' Awareness about Service Delivery Improvement of CBE

\begin{tabular}{|l|l|l|}
\hline $\begin{array}{l}\text { Customers awareness } \\
\text { about the banks' new } \\
\text { service delivery system }\end{array}$ & Frequency & $\mathbf{\%}$ \\
\hline YES & 96 & 96 \\
\hline No & 4 & 4 \\
\hline Total & $\mathbf{1 0 0}$ & $\mathbf{1 0 0}$ \\
\hline $\begin{array}{l}\text { Customers input for the new } \\
\text { system }\end{array}$ & Frequency & $\mathbf{\%}$ \\
\hline YES & 32 & 32 \\
\hline No & 68 & 68 \\
\hline Total & $\mathbf{1 0 0}$ & $\mathbf{1 0 0}$ \\
\hline
\end{tabular}

Table 4.2, depicted above, shows Customers feedback on their awareness about the improvements made in the service delivery after the BPR. Almost all of the customers have the noticed about implementation of new system of service delivery. On the same table customers have forwarded their idea on the involvement of their idea on the new system.

In this case most respondents have confirmed that the bank didn't use customers input in rearranging the new service delivery process. 


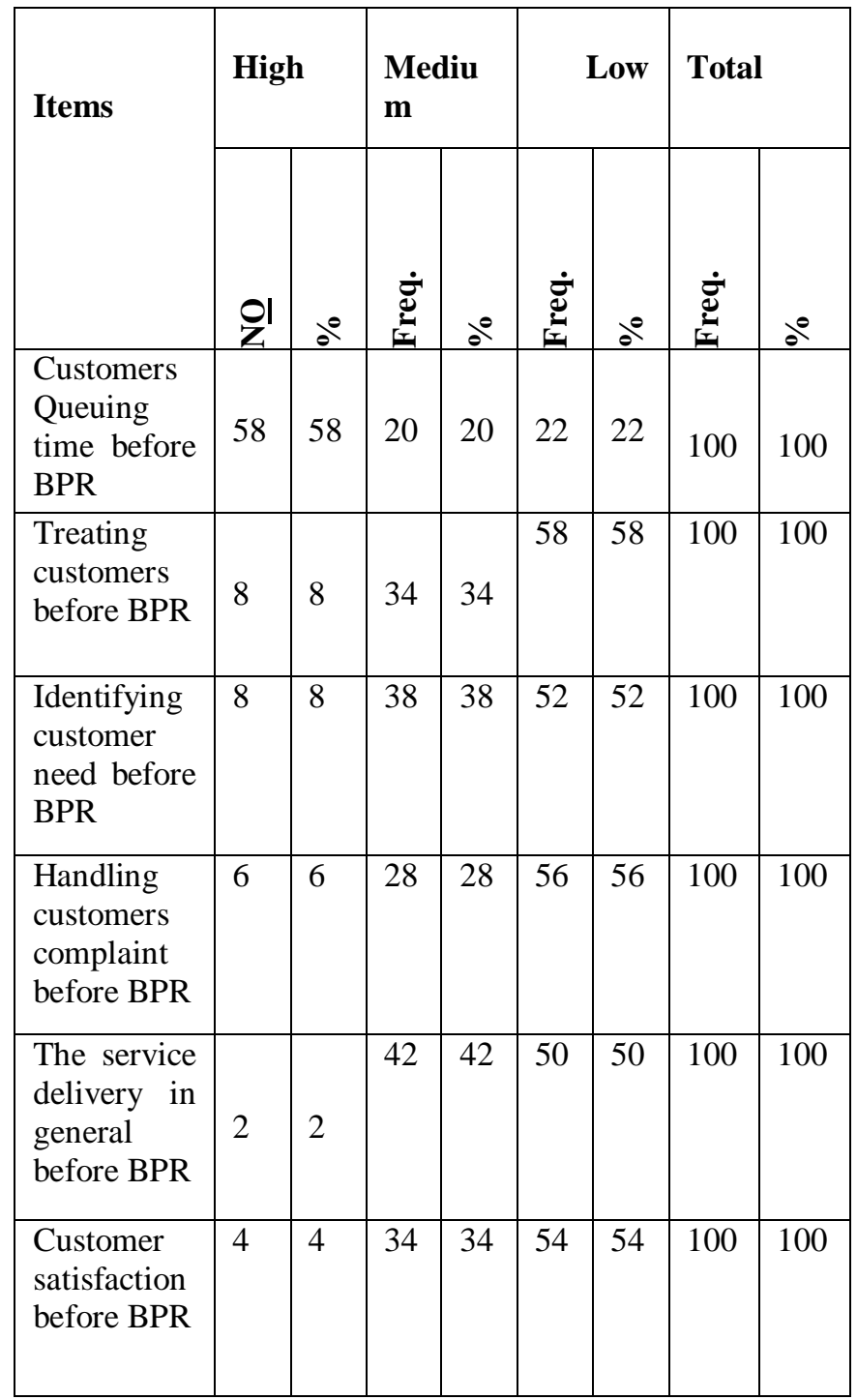

Table4.3.The Banks Service Delivery Before BPR

Table 4.3, displayed below, summarizes the factors that determine the service delivery of the bank before the reengineering process. It starts with the customers' feedback about queuing time in getting service. According to the data, around $78 \%$ of the customers believed that the customers queuing time was more than tolerable. This makes customers disappointed by the service delivery of the bank.

On the same table respondents still have negative feeling on treatment of customers and identifying the customers need before the new system is implemented which accounts the greatest percentage, i.e. $58 \%$, and $52 \%$ of the customers. It was also indicated by the research that the bank customers' complaint handling culture was poor and this was supported by $56 \%$ of the target respondents considered in the study. Finally, customers have forwarded their general comments on the general service given by the bank and their satisfaction level. The data shows that before implementing the new system the service delivery process was not as such satisfactory which is supported by more than 50 and $54 \%$ of the customers.

Generally, it is clearly outlined that the service delivery process used in the bank before reengineering the structure was problematic and not customer focused.

Table 4.4. Queuing Time in Each Service Type (Before BPR)

\begin{tabular}{|c|c|c|c|c|c|c|c|c|}
\hline \multirow[t]{2}{*}{$\begin{array}{l}\text { Type of } \\
\text { service }\end{array}$} & \multicolumn{2}{|c|}{10 min. } & \multicolumn{2}{|c|}{$\begin{array}{l}20 \\
\text { Min. }\end{array}$} & \multicolumn{2}{|c|}{$\begin{array}{l}30 \\
\text { Min. }\end{array}$} & \multicolumn{2}{|c|}{$\begin{array}{l}>30 \mathrm{mi} \\
\text { n. }\end{array}$} \\
\hline & $\Sigma^{\circ}$ & $\partial^{0}$ & je & $\check{L}^{\circ}$ & de & $\check{L}^{\circ}$ & se & $\perp^{\circ}$ \\
\hline Depositing & 9 & 9 & $\begin{array}{l}2 \\
1\end{array}$ & 21 & $\begin{array}{l}1 \\
6\end{array}$ & 16 & $\begin{array}{l}5 \\
0\end{array}$ & $\begin{array}{l}5 \\
0\end{array}$ \\
\hline Withdrawing & 6 & 6 & $\begin{array}{l}3 \\
4\end{array}$ & 34 & - & - & $\begin{array}{l}5 \\
6\end{array}$ & $\begin{array}{l}5 \\
6\end{array}$ \\
\hline Transferring & 6 & 6 & $\begin{array}{l}2 \\
2\end{array}$ & 22 & $\begin{array}{l}1 \\
4\end{array}$ & 14 & $\begin{array}{l}5 \\
4\end{array}$ & $\begin{array}{l}5 \\
4\end{array}$ \\
\hline $\begin{array}{l}\text { Processing } \\
\text { cheque }\end{array}$ & 6 & 6 & $\begin{array}{l}1 \\
4\end{array}$ & 14 & $\begin{array}{l}5 \\
2\end{array}$ & 52 & $\begin{array}{l}1 \\
2\end{array}$ & $\begin{array}{l}1 \\
2\end{array}$ \\
\hline
\end{tabular}

The following table summarizes the customers' feedback about the time they spent to get service before the bank has implemented the new way of business process. The bank is usually providing such service as cash deposit, cash withdraw, local and international money transfer, and cheque processing. While the first three service types are taking 30 minutes according to majority of the customers, the fourth type-cheque processing taking more than 30 minutes. These analyses are supported by more than 50,54 and $56 \%$ of the research participant respectively. In a modern service provision elapsing this much time for treating an individual customer is a significant time waste that may result in customer irritation.

Table 4.5.The Extent of Service Delivery Improvement After BPR

\begin{tabular}{|l|l|l|l|l|l|l|}
\hline \multirow{2}{*}{ ITEM } & \multicolumn{2}{|l|}{$\begin{array}{l}\text { Radicall } \\
\text { y }\end{array}$} & \multicolumn{2}{l|}{$\begin{array}{l}\text { Relati } \\
\text { vely }\end{array}$} & \multicolumn{2}{l|}{$\begin{array}{l}\text { Not at } \\
\text { all }\end{array}$} \\
\cline { 2 - 7 } & Fre & \% & $\begin{array}{l}\text { Fr } \\
\text { e. }\end{array}$ & \% & $\begin{array}{l}\text { Fre } \\
\text { q. }\end{array}$ & \% \\
\hline $\begin{array}{l}\text { Speed of } \\
\text { service } \\
\text { delivery }\end{array}$ & 51 & 51 & 37 & 37 & 2 & 2 \\
\hline $\begin{array}{l}\text { Customer } \\
\text { handling }\end{array}$ & 22 & 25 & 52 & 59 & 14 & 16 \\
\hline
\end{tabular}




\section{International Journal of Engineering Applied Sciences and Technology, 2019 \\ Vol. 4, Issue 6, ISSN No. 2455-2143, Pages 29-36 \\ Published Online October 2019 in IJEAST (http://www.ijeast.com)}

\begin{tabular}{|l|l|l|l|l|l|l|}
\hline $\begin{array}{l}\text { Knowing } \\
\text { customers need }\end{array}$ & 22 & 22 & 52 & 52 & 18 & 18 \\
\hline $\begin{array}{l}\text { Flexibility of } \\
\text { the procedures }\end{array}$ & 48 & 48 & 46 & 46 & 6 & 6 \\
\hline $\begin{array}{l}\text { Knowing } \\
\text { customers } \\
\text { complain }\end{array}$ & 32 & 32 & 58 & 58 & 10 & 10 \\
\hline
\end{tabular}

The above table presents the extent to which the service delivery activities are improved as the result of BPR implementation. The data gathered from the customers shows that while speed of service delivery and knowing customers complains are significantly or radically improved, customer treating, knowing customers need, and flexibility of the proceduresis improved relatively as compared to the previous system of delivery.

Table 4.6 Queuing Time in Each Service Type (After BPR)

\begin{tabular}{|c|c|c|c|c|c|c|c|c|}
\hline \multirow{2}{*}{$\begin{array}{l}\text { Type of } \\
\text { service }\end{array}$} & \multicolumn{2}{|c|}{$10 \mathrm{~min}$} & \multicolumn{2}{|c|}{20 Min. } & \multicolumn{2}{|c|}{30 Min. } & \multicolumn{2}{|c|}{$\begin{array}{l}\text { Above } \\
\text { That }\end{array}$} \\
\hline & se & $\dot{\Phi}$ & $s^{0}$ & $\dot{\vec{d}}$ & $s^{0}$ & ذ্ّ & $x^{\circ}$ & $\dot{\vec{\Xi}}$ \\
\hline Depositing & 2.0 & 2 & 14 & 14 & 24 & 24 & 60 & 60 \\
\hline $\begin{array}{l}\text { With } \\
\text { drawing }\end{array}$ & 4.0 & 4 & 6 & 6 & 28 & 28 & 62 & 62 \\
\hline $\begin{array}{l}\text { Transferrin } \\
\mathrm{g}\end{array}$ & 4.0 & 4 & 8 & 8 & 40 & 40 & 48 & 48 \\
\hline $\begin{array}{l}\text { Processing } \\
\text { cheque }\end{array}$ & 2.0 & 2 & 11 & 11 & 33 & 33 & 54 & 54 \\
\hline
\end{tabular}

Customers have forwarded their feedback on the improvements made after the implementation of new system considering the four service factors, the cash deposit, cash withdrawing, transfer service, and Processing cheque. The time spent for serving customers in all dimensions is significantly improved after the bank implemented the new system.

As the essence of BPR is radical improvement in the business process, the changes achieved in the service delivery are considered to be partial improvements as far as CBE is concerned. From this perspective BPR is not completely effective in the selected branches of the bank.

\section{CONCLUSION}

This study was intended to evaluate the effectiveness of BPR in the selected bank considering the results achieved after the new system. Based on the data from the analysis, it is possible to generalize the following points: in terms of queuing time the new system has come up with a radical change in all type of services- in depositing, transfer, withdrawing and in processing cheque. However, in customer handling understanding customers' needs, and handling customers complain, the changes are treated as a relative changes. As per the BPR recommendation, the business process needs to be radically changed so that the new system is said to be effective enough.

To this end, the author likes to recommend that, the bank need to revise the work process particularly in identifying the customer needs and in managing customer's complaints. Appropriate follow up is required for the application of new system. It is better to consider reassigning tasks in customer service offices, better to have frequent customer contact to gather the necessary feedback and take the actions as per the demand of the new system.

\section{REFERENCES}

[1]. Davenport, Thomas (1993), Process Innovation: Reengineering work through information technology, Harvard Business School Press,

[2]. Hammer and Champy (1993) Reengineering the Corporation: A Manifesto for Business Revolution

[3]. Hezron M. Osano, David M. Okwena 2011 Factors Influencing Performance of Business Process Reengineering Projects in Banks in Kenya: Case of Kenya Commercial Bank: Journal of US-China Public Administration, November 2015, Vol. 12, No. 11,

[4]. Kothari, C.R.,1985, Research MethodologyMethods and Techniques, New Delhi, Wiley Eastern Limited.

[5]. Kumar, Ranjit, 2005, Research Methodology-A Step-by-Step Guide for Beginners, (2nd.ed), Singapore, Pearson Education.

[6]. Michael Hammer, James A. Champy. Reengineering the Corporation: Manifesto for Business Revolution. HarperCollins, 1993. p. 11

[7].Michael Hammer in: Fortune, August 1993. The Ultimate Resource, 4th edition. Blooms bury Publishing - 2013. 
[8]. Sidikat, A. (2008). Impact assessment of business process reengineering on organizational performance. European Journal of Social Sciences, (pp. 115-125.)

[9]. Baron S. and Harris K. 1995, 2003 Services Marketing Text and Cases $2^{\text {nd }}$ Ed. (pp. 136-144) [10]. Satyanarayana S. V. and Kavitha N. V. (2011), Impact of Business Process ReEngineering in Commercial Banks on Customers A case study of State Bank of Hyderabad.

[11]. Yih-Chang Chen (2001) "Empirical Modelling for Participative Business Process Reengineering, The Universy of WARWICK

[12]. Mudie P. And Pirrie A. (2006) Services Marketing Management, 3rd Ed. Published By Elsevier Ltd. (pp. 30 - 33)

[13]. Hoffman D. and Bateson J E. (2008) Services Marketing Concepts, Strategies, \& Cases $4^{\text {th }}$. Ed. South-Western Cengage Learning Ltd. (pp 288-293 